\title{
A possible solution to minimize scotta as a food waste: a sports beverage
}

\begin{tabular}{|r|l|}
\hline Journal: & International Journal of Dairy Technology \\
\hline Manuscript ID & IJDT-0117-19.R5 \\
\hline Manuscript Type: & Original Research \\
\hline Dute Submitted by the & 26-Jul-2019 \\
\hline Complete List of Authors: & $\begin{array}{l}\text { tirloni, erica; Department of Health, Animal Science and Food Safety, } \\
\text { Università degli Studi di Milano } \\
\text { Vasconi, Mauro; Department of Health, Animal Science and Food Safety, } \\
\text { Università degli Studi di Milano } \\
\text { Cattaneo, Patrizia; Department of Health, Animal Science and Food } \\
\text { Safety, Università degli Studi di Milano } \\
\text { Moretti, Vittorio; Department of Health, Animal Science and Food Safety, } \\
\text { Università degli Studi di Milano } \\
\text { Bellagamba, Federica; Department of Health, Animal Science and Food } \\
\text { Safety, Università degli Studi di Milano } \\
\text { Bernardi, Cristian; Department of Health, Animal Science and Food } \\
\text { Safety, Università degli Studi di Milano } \\
\text { Stella, Simone; Department of Health, Animal Science and Food Safety, } \\
\text { Università degli Studi di Milano }\end{array}$ \\
\hline Keywords: & $\begin{array}{l}\text { Dairy microbiology, Microbiology, New product development, Shelf life, } \\
\text { Whey, Yeasts }\end{array}$ \\
\hline
\end{tabular}


Milan, July, 26, 2019

Editorial Office: International Journal of Dairy Technology

Please find enclosed the revised manuscript: "A possible solution to minimize scotta as a food waste: a sports beverage" by Tirloni Erica, Vasconi Mauro, Cattaneo Patrizia, Moretti Vittorio Maria, Bellagamba Federica, Bernardi Cristian and Stella Simone.

For any communication concerning the manuscript, please contact me as the corresponding author:

Erica Tirloni

Department of Health, Animal Science and Food Safety, University of Milan

Via Celoria 10

I-20133 Milan, Italy

Phone: +3902 50317855

Fax: $\quad+390250317870$

email: erica.tirloni@unimi.it

Thanking you in advance for your attention,

Erica Tirloni 


\section{A possible solution to minimize scotta as a food waste: a sports beverage}

2

3 Running head: Scotta as a beverage

4

5 Tirloni E. ${ }^{1}$, Vasconi M. ${ }^{1}$, Cattaneo P. ${ }^{1}$, Moretti V. ${ }^{1}$, Bellagamba F. ${ }^{1}$, Bernardi C. ${ }^{1}$, Stella S. ${ }^{1}$

6

71 Department of Health, Animal Science and Food Safety, Università degli Studi di Milano, Via 8 Celoria 10, IT-20133, Milan, Italy

9

$10 *$ corresponding author:

11 Erica Tirloni, Department of Health, Animal Science and Food Safety, Università degli Studi di 12 Milano, Via Celoria 10, IT-20133, Milan, Italy.

13 erica.tirloni@unimi.it

14 Tel: 02-50317855 


\section{Abstract}

16 A pilot study-trial was performed on ready to drink beverages produced in a small-scale dairy 17 plant starting from Ricotta whey (scotta) with the addition of fruit puree and starter cultures. 18 Microbiological shelf-life was evaluated at 4 and $12^{\circ} \mathrm{C}$. At $4^{\circ} \mathrm{C}$ the product showed moderate 19 total viable counts until the end of the trial ( $\sim \log \mathrm{cfu} / \mathrm{mL}$ ). Yeasts proved to be the specific 20 spoilage microorganisms of the product. When applying a thermal abuse at $20^{\circ} \mathrm{C}$ for $6 \mathrm{~h}$, TVC 21 did not increase. The addition of fruit puree changed the volatile profile of the beverages 22 compared to raw scotta.

\section{Keywords:}

25 Dairy microbiology; Microbiology; New product development; Shelf life; Whey; Yeasts. 


\section{Introduction}

Dairy products, although providing all the crucial nutrients being included in a daily balanced diet, have a negative impact on environment in terms of resource disposal and greenhouse emissions. Moreover, dairy industry produces a major part of liquid wastes, (Gonzales-Garcia et al. 2013). It is considered that worldwide whey production is around 180190 million tons/year, with an increase of $2 \%$ per year (Mollea et al. 2013).

Wastes and wastewaters deriving-from dairy industry are characterized by the presence of complex contents difficult to degrade such as lactose and in minor part proteins, lipids, vitamins, salts, and pollutant remains like chemicals deriving from cleaning procedures (Palmieri et al. 2017; Ahmad et al. 2019).

Cheese whey is a yellowish by-product fluid obtained from cheese-making and casein manufacture in the dairy industry; it is the residual liquid remaining after curd separates from millk following caseins' coagulation-(Zadow 1994). Scotta is the end-product of Ricotta cheese, a dairy product obtained from cheese whey after acid-heat coagulation and precipitation of whey proteins. In Italy, according to Sansonetti et al. (2009), about $15 \%$ of whey is used for Ricotta production, resulting in more than 1 million tons of scotta per year.

In the past, cheap and easy solutions were used by dairy producers to discard cheese whey and scotta, such as vaporization of the product on fields or elimination in rivers, lakes or the ocean. This approach is nowadays negatively felt worldwiue, due to the polluting power of cheese whey; moreover, strict environmental legislations have been introduced to avoid improper dumping and to find out new opportunities to reuse these effluents (Smithers, 2008). Although having many implications as pollutants, cheese whey and scotta maintain a biological and nutritional value that are exploited only in small part. Nowadays, a minor fraction of whey is recycled and transformed in valuable products (e.g. animal feed, pharmaceutical industry, or industries which produce infants' dried powder) (Guimarães et al. 2018; Monteiro et al. 2018). Recent surveys have showed the potentiality of transformation of cheese whey into yeast bioprotein, bioethanol production, starter cultures, functional and nutritional proteins and 
53 bioactive peptides (Yadav et al. 2015; Nam et al. 2016; Stankey et al. 2017; Kaminarides et 54 al. 2018).

Considering scotta, few studies have focused on the possible use of this substrate for the production of fermented drinks (Maragkoudakis et al. 2006), for obtaining lactose by crystallization (Pisponen et al 2013), or obtaining lactic acid by LAB (Pescuma et al. 2008; Secchi et al. 2012) and bio-ethanol by yeasts fermentation (Sansonetti et al. 2009; Zoppellari and Bardi 2013).

Another possibility is to explore its use for sports beverages, that are turning more often to whey proteins for their special functionality and high nutritional properties; some examples are currently on the market, although only Maragkoudakis et al. (2006) approached the evaluation of a potential new drink in Italy.

In the present study, a pilot production of a ready to drink beverage produced starting from Ricotta cheese whey (scotta) was considered. Shelf-life at different temperatures was determined and the potential thermal abuse was also investigated.

\section{Materials and methods}

\section{Beverages preparation}

In the present study a microbiological shelf-life of scotta beverages obtained from the remained scotta after Ricotta production, was conducted. Two starter cultures used also for yogurt production (Lactobacillus delbrueckii subsp. bulgaricus and Streptococcus thermophilus) were added to scotta; these cultures were mixed into it, maintained at $42^{\circ} \mathrm{C}$ until the $\mathrm{pH}$ reached almost 4. Afterwards, the beverages were cooled at $4^{\circ} \mathrm{C}$ to stop the fermentation process. Then, two different commercial pasteurized purees were added (550 $\mathrm{g}$ for $4 \mathrm{~L}$ of scotta), which consisted in sugar, tropical (mango flavoured) or citrus fruits (35\%), water, gelling agent: pectin E440, flavouring, preservative: E202 - potassium sorbate (0.13\%), acidity regulator: sodium citrate - E331. The two types of beverage were packaged into 125 $\mathrm{mL}$ bottles and submitted to the subsequent tests. Each of the two series (citrus or tropical beverages) was stored at two different static temperatures $\left(4\right.$ and $\left.12^{\circ} \mathrm{C}\right)$. 
At settled sampling times $(0,7,14,21$, and 28 days from the production) the samples stored at $4^{\circ} \mathrm{C}$ or at $12^{\circ} \mathrm{C}$ were analysed in triplicate.

\section{Microbiological shelf-life}

For microbial counting, $10 \mathrm{~mL}$ of each sample were homogenized in $90 \mathrm{~mL}$ of a diluent solution $(0.85 \% \mathrm{NaCl}$ and $0.1 \%$ tryptone), and serial 10 -fold dilutions were prepared. Total mesophilic count (TMC) excluding Lactic Acid Bacteria was determined using gelatine peptone bios agar (AG) (Biogenetics, Ponte San Nicolò, Italy), subsequently incubated at $30^{\circ} \mathrm{C}$ for $48 \mathrm{~h}$. L. delbrueckii subsp. bulgaricus was enumerated on de Man-Rogosa-Sharpe agar (Oxoid, Basingstoke, UK), acidified at pH 5.2 according to ISO/FDIS 7889 IDF 117 standard (ISO, 2002). S. thermophilus was counted onto M17 agar (Oxoid) supplemented with lactose (5 g/L) and incubated under aerobic conditions at $45^{\circ} \mathrm{C}$ for $24 \mathrm{~h}$ (IDF, 1981); this medium, although not strictly selective, is very often applied for the enumeration of lactic streptococci in milk and dairy products. Enterobacteriaceae were enumerated by the ISO 21528-2:2017 method. Escherichia coli were enumerated according to the ISO 16649-2:2001 method. Coagulasepositive Staphylococci were determined by the ISO 6888-1:2018 method. Yeasts and moulds were enumerated according to ISO 21527-1:2008 method. Bacillus cereus was enumerated onto PEMBA agar (Biogenetics) and incubated at $30^{\circ} \mathrm{C}$ for $48 \mathrm{~h}$ (ISO 7932:2004). Salmonella spp. detection was performed by ISO 6579:2017/Cor 1:2017 methods. Finally, detection of Listeria monocytogenes was performed according to the AFNOR method (AFNOR BRD 07 / 4$09 / 98)$.

At the same sampling times, $\mathrm{pH}$ was measured by a $\mathrm{pH}$ meter (Amel instruments, Milano, I): three independent measurements were performed on each sample and means were calculated.

Moreover, a thermal abuse by maintaining the two series of products at $20^{\circ} \mathrm{C}$ for $6 \mathrm{~h}$ was applied, simulating the likely duration of the product by an individual during prolonged physical activity. The same parameters reported above were considered and analyses were performed in triplicate.

\section{Volatile compounds analysis}


107 The volatile compounds analysis of the experimental beverages was made using headspace 108 solid-phase microextraction coupled with gas chromatography-mass spectrometry (HS-SPME109 GC-MS). Analysis was carried on raw scotta used for the preparation of the 2 sport beverages, 110 one day after the addition of the starter culture, as described above, and after the addition of citrus and tropical flavour. Then samples of the two beverages were analysed at the end of the trial, both those kept at 4 and those at $12^{\circ} \mathrm{C}$. Quickly $5 \mathrm{ml}$ of scotta and experimental sport beverages were transferred in a $20 \mathrm{~mL}$ vial, then $1 \mathrm{~g}$ of $\mathrm{NaCl}$ was added. After that, vials were closed by a PTFE / silicone cover, and shaken for 5 minutes to allow salt dissolution. Before extraction, stabilization of the headspace in the vial was obtained by equilibration for 20 mins at $40^{\circ} \mathrm{C}$, using a multi-purpose sampler MPS2 XL (Gerstel $\mathrm{GmbH}$, Mülheim an der Ruhr, Germany) equipped with the SPME option. Extraction and analysis of volatile compounds were made using the methods described in our precedent work on dairy products (Tirloni et al. 2018).

\section{Statistical analysis}

Microbiological and chemical-physical results obtained at the different sampling time were subjected to statistical analysis through ANOVA test. A probability of $P<0.05$ and $P<0.01$ was considered as a threshold value for statistically significant differences.

\section{Results and discussion}

In this study, a pilot production of a ready to drink beverage prepared starting from Ricotta cheese whey (scotta) was investigated. Two series were considered, based on the flavour of puree added after production: citrus or tropical flavour. The two series of beverages were maintained at 2 static temperatures $\left(4^{\circ} \mathrm{C}\right.$, thus ideal refrigeration and $12^{\circ} \mathrm{C}$ mimicking a thermal abuse) to determine their microbiological shelf-life. To improve their functional value, starter cultures used in yogurt production (S. thermophilus and L. delbrueckii subsp. bulgaricus) were also added to the beverages.

Considering S. thermophilus counts, the profucts were stable at the 2 temperatures considered with loads always above $7 \log \mathrm{cfu} / \mathrm{mL}$ in all samples. S. thermophilus population 
134 was stable during the storage period at the two temperatures: at $4^{\circ} \mathrm{C}$ in citrus flavour samples, 135 the loads ranged from $8.09 \log \mathrm{cfu} / \mathrm{mL}(\mathrm{d} 0)$ to $8.33 \log \mathrm{cfu} / \mathrm{mL}(\mathrm{d} \mathrm{28}$ ), whereas in tropical 136 flavour samples, the loads were from $8.07 \log \mathrm{cfu} / \mathrm{g}\left(\mathrm{d} 0\right.$ ) to $8.39 \log \mathrm{cfu} / \mathrm{mL}$ (d 28). At $12^{\circ} \mathrm{C}$, 137 S. thermophilus, in citrus flavour samples, showed loads from 7.48 log cfu/mL (d 0 ) to 8.25 $\log \mathrm{cfu} / \mathrm{mL}$ ( $\mathrm{d} \mathrm{28}$ ), whereas in tropical flavour samples, the loads were from $8.21 \mathrm{log} \mathrm{cfu} / \mathrm{g}$ ( $\mathrm{d}$ 0) to $8.39 \log \mathrm{cfu} / \mathrm{mL}(\mathrm{d} \mathrm{28})$.

Considering $L$. delbrueckii subsp. bulgaricus counts, the products showed very low loads at T0, with counts always below $4 \log \mathrm{CFU} / \mathrm{mL}$ in all samples stored at $4^{\circ} \mathrm{C}$. At $12^{\circ} \mathrm{C}$ in citrus flavour samples, the loads ranged from $3.41 \log \mathrm{cfu} / \mathrm{mL}(\mathrm{d} 0)$ to $7.44 \log \mathrm{cfu} / \mathrm{mL}$ (d 28), whereas in tropical flavour samples, the loads were from $3.39 \log \mathrm{cfu} / \mathrm{mL}$ (d 0 ) to $7.48 \log$ $\mathrm{cfu} / \mathrm{mL}$ ( $\mathrm{d}$ 28). We could hypothesize that for this typology of substrate (rich in lactose but substantially poor in any other nutrient), a selection of specific Lactic Acid Bacteria would be convenient to optimize their ability of fermentation, in order to optimize their performances.

Lactic acid bacteria were generally the predominant microflora due to the inoculation of starter cultures (especially due to the ability of fermentation of S. thermophilus), as already reported for dairy products like yogurt or similar, where starter cultures are added (Mataragas et al. 2011; Tirloni et al. 2015).

Considering Total Viable Count (TVC) at $4^{\circ} \mathrm{C}$ (Figure 1), the beverages showed low loads for the whole sampling period ( $28 \mathrm{~d}$ ): at $4^{\circ} \mathrm{C}$ in citrus flavour samples, the loads ranged on average from $4.16 \log \mathrm{cfu} / \mathrm{mL}$ ( $\mathrm{d} 0$ ) to $4.84 \mathrm{log} \mathrm{cfu} / \mathrm{mL}$ ( $\mathrm{d} 28$ ), whereas in tropical flavour samples at $4^{\circ} \mathrm{C}$, the loads were on average from $4.31 \mathrm{log} \mathrm{cfu} / \mathrm{mL}$ (d 0 ) to $5.76 \log \mathrm{cfu} / \mathrm{mL}$ ( $\mathrm{d}$ 28). At $12^{\circ} \mathrm{C}, \mathrm{TVC}$, in citrus flavour samples, showed final loads on average of $5.74 \mathrm{log} \mathrm{cfu} / \mathrm{mL}$ ( $d$ 28), whereas in tropical flavour samples, the final loads were on average above 6 log $\mathrm{cfu} / \mathrm{mL}(\mathrm{d} \mathrm{28})$.

Yeasts were the restrictive factor for the limitation of the product's microbiological shelf-life: these microorganisms, that are also the specific spoilage organisms for yogurt, showed to be able to express their metabolic activity, in terms of fermentation of lactose 
considering yeasts (Figure 2), the products generally showed loads below the detection limit (2 Log $\mathrm{cfu} / \mathrm{mL}$ ) at T0 except for the beverage with tropical flavour at $12^{\circ} \mathrm{C}$ where a low countable load was detected (2.15 \pm 0.21$)$. During the storage at $4^{\circ} \mathrm{C}$ a slight and gradual increase was observed reaching final loads on average equal to 4.62 and $5.48 \mathrm{log} \mathrm{cfu} / \mathrm{mL}$ in citrus and tropical flavour beverages. During the storage at $12^{\circ} \mathrm{C}$, an increase was observed reaching final loads, on average, equal to 5.90 and $5.47 \mathrm{log} \mathrm{cfu} / \mathrm{mL}$ in citrus and tropical flavour beverages, respectively. A limit of $5 \mathrm{log} \mathrm{cfu} / \mathrm{g}$ has previously been reported as a threshold limit above which consumers may perceive a sensorial alteration (Suriyarachchi and Fleet, 1981): in citrus flavour beverages at $4^{\circ} \mathrm{C}$ this limit was never exceeded, while at $4^{\circ} \mathrm{C}$ in tropical flavour beverages this limit was overcome after only 14 days of storage. At $12^{\circ} \mathrm{C}$, in citrus flavour beverages the load of 5 log cfu/mL was overcome after 22 days of storage and only after 14 days in in tropical flavour beverages.

E. coli, Enterobacteriaceae, coagulase-positive staphylococci, Bacillus cereus and moulds were below the detection limit (2 log CFU/mL) at all sampling times. Salmonella spp. and $L$. monocytogenes were always absent in $25 \mathrm{~g}$ of product at all sampling times.

$\mathrm{pH}$ values were generally constant in the beverages at all sampling times, without any clear trend with values on average, ranging between 4.09 and 3.98 (4 $\mathrm{C}$-citrus), 4.09 and 3.92 ( $4^{\circ} \mathrm{C}$-tropical), 4.07 and $3.94\left(12^{\circ} \mathrm{C}\right.$-citrus) and 4.07 and 4.08 (12 ${ }^{\circ} \mathrm{C}$-tropical).

Considering a possible thermal abuse simulating a prolonged sports activity (in this case $20^{\circ} \mathrm{C}$ for $6 \mathrm{~h}$ ), no increase was observed in TVC in both the series (citrus and tropical) (citrus: $\mathrm{T} 0=3.57 \pm 0.07, \mathrm{~T} 6 \mathrm{~h}=3.43 \pm 0.07 ; \quad$ tropical: $\mathrm{T0}=3.34 \pm 0.48, \mathrm{~T} 6 \mathrm{~h}=3.53 \pm 0.10) . \quad$ Yeasts, Escherichia coli, Enterobacteriaceae, coagulase-positive staphylococci, Bacillus cereus and moulds were at all sampling times below the detection limit ( $2 \log \mathrm{CFU} / \mathrm{mL}$ ), while Salmonella spp. and L. monocytogenes were absent in the two sampling times.

The volatile organic compounds found in scotta and the two experimental beverages at T0 are shown in Table 1. Data are expressed as a percentage of total ion count area of all volatile compounds identified. The addition of fruit puree changed almost completely the volatile profile of the beverages if compared with raw scotta. Raw scotta volatile profile was constituted 
190 mainly by ketones, followed by acids and alcohols. This product is the derivation of two 191 previous processes; the first one used raw milk in cheese production, resulting in whey, which 192 in turn, following a second processing, produces Ricotta and its by-product, scotta. The volatile 193 compounds found in scotta are the results of these two processing phases, where thermal

treatments and oxidation produced an increase of free fatty acids and the product of their degradation, such as aldehydes and ketones. This pattern was also described by Bergamaschi and Bittante (2018), who analysed the volatile compounds profile of various dairy products, from milk to scotta, considering all the intermediate products. Authors found a progressive increase of volatile organic compounds, with the higher concentration among not ripened product found in whey and scotta, where free fatty acids, aldehydes and ketones were found at the highest concentrations. This volatile pattern is not suitable for direct scotta consumption, since these substances are associated with odour descriptors of rancid (Zabaleta et al. 2016). For instance, straight chain aldehydes, like nonanal ones, are responsible for unpleasant odour when they exceed their odour thresholds (Curioni and Bosset 2002). To correct the off flavour two experimental flavouring purees were tested.

The beverage in which a citrus puree was added presented a volatile profile dominated by terpenes, while in tropical fruit beverages a prevalence of esters and terpenes was found. In the citrus aroma beverage, as expected, limonene represented almost $93 \%$ of the total volatile compounds isolated, while in tropical fruit beverage 2-hexen-1-ol acetate was the prevalent compound.

Figure 3 shows the variation of diacethyl, ethyl alcohol and ethyl acetate in citrus flavour beverage $(A)$ and tropical fruit $(B)$ sampled at the end of the trial at $4{ }^{\circ} \mathrm{C}$ and $12^{\circ} \mathrm{C}$ and at the beginning of shelf-life test. Ethyl alcohol increased considerably in both beverages stored at thermal abuse, reaching a total ion current (TIC) 30 and 40 times higher for tropical and citrus beverages respectively, against those maintained at $4^{\circ} \mathrm{C}$. In those samples, ethyl alcohol was found in a similar concentration if compared to the one measured at T0. A similar trend, even if with a slower increase, was found in ethyl acetate concentrations: this was probably due to yeasts' metabolism. Butanoic acid ethyl ester, or ethyl butyrate, a compound typically found in 
218 mature fruits, deriving from the formal condensation of the hydroxy group of ethanol with the 219 carboxy group of butyric acid. As it derives from ethanol, its trend followed its precursor's, with 220 an increase during the preservation period. Diacetyl is an important component in the flavour 221 of food and it is known to be the chief component of the aroma of butter. This substance plays an important role in the formation of off-flavour aroma in beer when fermentation continues in a way that is not appropriate to the correct process (Krogerous et al. 2015). In dairy products diacetyl is formed by lactic acid bacteria starting from citrate or lactose, if citrate is not present in growth substrate (Hugenholtz and Starrenburg, 1992). During the storage period we didn't find a significant increase of this compound in citrus flavoured beverages, while it increased in tropical fruit beverages, without differences between the two storage temperatures. Acetaldehyde (data not shown in figure 3) increased during the trial, but no differences between the two storage temperatures were found. Acetoin derives from the degradation of diacetyl. The formation of this compound showed a different trend in the two beverages: in particular, it increased in tropical fruit beverages, especially in samples subjected to thermal abuse, while in citrus beverages it was found in higher concentration at the beginning of the trial, compared to the end of the shelf-life test.

These data should be coupled in future with further sensorial analyses attesting good sensory acceptance and consumers' expectations. As already stated by Krešić et al. (2010) and Ahmadi et al. (2018), the use of whey in dairy beverages could be a promising substitute for dairy industries, as they are considered positively by consumers.

\section{Conclusions}

From a microbiological point of view, yeasts proved to be the limiting factor for shelf-life, exceeding the threshold of $5 \mathrm{log} \mathrm{cfu} / \mathrm{mL}$ in citrus beverages $\left(12^{\circ} \mathrm{C}\right.$ of storage) and in tropical beverages $\left(4^{\circ} \mathrm{C}\right.$ and $12^{\circ} \mathrm{C}$ of storage) only after 14 days of storage. The addition of starter cultures seems promising, although a specific selection of natural Lactic Acid Bacteria would increase the performances especially during the substrate fermentation. The addition of fruit puree changed completely the volatile profile of the two beverages compared to raw scotta. 
245 When a strong thermal abuse $\left(20^{\circ} \mathrm{C}\right)$ was applied, TVC did not show an increase, confirming 246 the suitability of use as sport drinks 


\section{References}

248 Ahmad T, Aadil R A, Ahmed H, Rahman U, Soares B C V, Souza S L Q, Pimentel TC, Scudino H, 249 Guimarães J T, Esmerino E A, Freitas M Q, Almada R B, Vendramel S M R, Silva M C and Cruz 10250 11 A G (2019) Treatment and utilization of dairy industrial waste: A review. Trends in Food Science \& Technology 88 361-372.

Ahmadi S F, Nasirpour A, Goli S A H and Riahi E (2018) Effect of heat treatment and solution preparation procedure on colloidal stability of whey protein sour cherry beverage. International Journal of Dairy Technology 71781-790.

González-García S, Hospido A, Moreira MT, Feijoo G and Arroja L (2013) Environmental Life Cycle Assessment of a Galician cheese: San Simon da Costa. Journal of Cleaner Production $\mathbf{5 2}$ 253-262.

Guimarães J T, Silva E K, Alvarenga V O, Costa A L R, Cunha R L, Sant'Ana A S, Freitas M Q, Meireles AA and Cruz AG (2018) Physicochemical changes and microbial inactivation after high-intensity ultrasound processing of prebiotic whey beverage applying different ultrasonic power levels. Ultrasonics Sonochemistry 44 251-260.

Hugenholtz J and Starrenburg M J C (1992) Diacetyl production by different strains of Lactococcus lactis subsp. lactis var. diacetylactis and Leuconostoc spp. Applied Microbiology Biotechnology 3817.

IDF (1981) Identification and enumeration of microorganisms in fermented milks. Joint IDF/ISO/AOAC Group E44.

Jakobsen M and Narvhus J (1996) Yeasts and their possible beneficial and negative effects on the quality of dairy products. International Dairy Journal 6 755-768.

Kaminarides S, Aktypis A, Koronios G, Massouras T and Papanikolaou S (2018) Effect of 'in situ' produced bacteriocin thermophilin $\mathrm{T}$ on the microbiological and physicochemical 
271 characteristics of Myzithra whey cheese. International Journal of Dairy Technology 71 213272222.

273 Krešić G, Herceg Z, Lelas V and Jambrak A R (2010). Consumers' behaviour and motives for selection of dairy beverages in Kvarner region: A pilot study. Mljekarstvo 60 50-58.

Krogerus K, Gibson B and Hytönen E (2015) An Improved Model for Prediction of Wort Fermentation Progress and Total Diacetyl Profile. Journal of the American Society of Brewing Chemists $73190-99$.

Maragkoudakis P A, Miaris C, Rojez P, Manalis N, Magkanari F, Kalantzopoulos G and Tsakalidou E (2006) Production of traditional Greek yoghurt using Lactobacillus strains with probiotic potential as starter adjuncts. International Dairy Journal 16 52-60.

Mataragas M V, Dimitriou P N, Skandamis P N, and Drosinos E H (2011) Quantifying the spoilage and shelf-life of yoghurt with fruits. Food Microbiology 28 611-616.

Mollea C, Marmo L and Bosco F (2013) Valorisation of Cheese Whey a By-Product from the Dairy Industry. Available at: file:///C:/Users/a/Downloads/42000.pdf

Monteiro S H M C, Silva E K, Alvarenga V O, Moraes J, Freitas M Q, Silva M C, Raices R S L, Anderson Sant'Ana S, Meireles M A A and Cruz A G (2018). Effects of ultrasound energy density on the non-thermal pasteurization of chocolate milk beverage. Ultrasonics Sonochemistry $\mathbf{4 2}$ 1-10

Nam S-H, Wagh A, Martini S and Walsh M K (2016) Sensory characterisation of a high-protein beverage. International Journal of Dairy Technology 70 432-438.

Palmieri N, Bonaventura Forleo M and Salimei E (2017) Environmental impacts of a dairy cheese chain including whey feeding: An Italian case study. Journal of Cleaner Production 140: 881-889. 
294 Pescuma M, Marìa Hèbert E, Mozzi F and Font de Valdez G (2008) Whey fermentation by 295 thermophilic lactic acid bacteria: Evolution of carbohydrates and protein content. Food 296 Microbiology 25 442-451.

Pisponen A, Pajumägi S, Mootse H, Karus A and Poikalainen V (2013) The lactose from Ricotta cheese whey: the effect of $\mathrm{pH}$ and concentration on size and morphology of lactose crystals. Dairy Science and Technology 93 477-486.

Sansonetti S, Curcio S, Calabro' V and Iorio G (2009) Bio-ethanol production by fermentation of Ricotta cheese whey as an effective alternative non-vegetable source. Biomass and bioenergy 33 1687-1692.

Secchi N, Giunta D, Pretti L, Ruiz García M, Roggio T, Mannazzu I and Catzeddu P (2012) Bioconversion of ovine scotta into lactic acid with pure and mixed cultures of lactic acid bacteria. Journal of Industrial Microbiology \& Biotechnology 39 175-181.

Smithers GW (2008) Whey and whey proteins-From 'gutter-to-gold'. International Dairy Journal 18 695-704.

Stankey J A, Lu Y, Abdalla A, Govindasamy-Lucey S, Jaeggi J J, Mikkelsen B $\varnothing$, Pedersen K T and Andersen C B (2017) Low-fat Cheddar cheese made using microparticulated whey proteins: Effect on yield and cheese quality. International Journal of Dairy Technology 70 481491.

Suriyarachchi V R and Fleet G H (1981) Occurrence and growth of yeasts in yoghurt. Applied Environmental Microbiology 42 574-579.

Tirloni E, Bernardi C, Colombo F and Stella S (2015) Microbiological shelf life at different temperatures and fate of Listeria monocytogenes and Escherichia coli inoculated in unflavoured and strawberry yogurts. Journal of Dairy Science 98 4318-4327.

Tirloni E, Vasconi M, Cattaneo P, Ravasio A, Pesenti E, Moretti V M, Bellagamba F, Stella S and Bernardi C (2018) Potentiality of the use of starter culture in PDO Strachitunt production on 
319 chemical-physical and microbiological features: A pilot study. LWT - Food Science and 320 Technology 98 124-133.

321 Yadav J S S, Song Yan Pilli S, Kumar L, Tyagi R D and Surampalli R Y (2015) Cheese whey: A 10322 potential resource to transform into bioprotein functional/nutritional proteins and bioactive 11 2323 peptides. Biotechnology Advances 33756-774.

15324 Zadow J G (1994) Utilization of milk components: Whey. In R. K. Robinson (Ed.) Modern dairy 17325 technology advances in milk processing Vol. 1 (2nd ed.) (pp. 313-373). London UK: Chapman 19326 and Hall.

327 Zoppellari F and Bardi L (2013) Production of bioethanol from effluents of the dairy industry by 328 Kluyveromyces marxianus. New Biotechnology 30 607-613. 

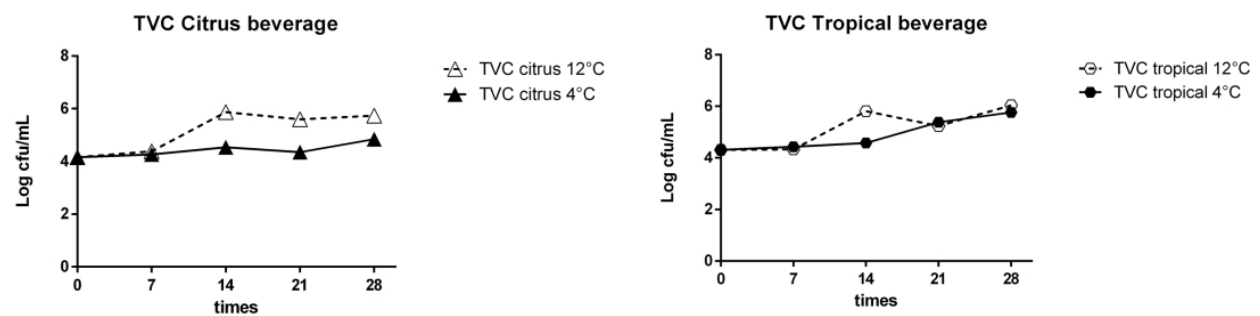

Total viable count of sports beverage maintained at 4 and $12^{\circ} \mathrm{C}$

$259 \times 74 \mathrm{~mm}(300 \times 300$ DPI $)$ 

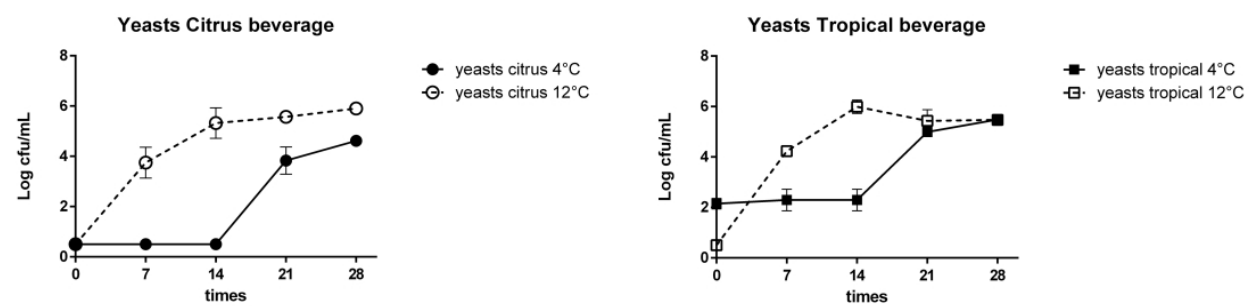

Yeasts count of sports beverage maintained at 4 and $12^{\circ} \mathrm{C}$ $207 \times 58 \mathrm{~mm}(600 \times 600 \mathrm{DPI})$ 
Tropical flavour

Ethyl Alcohol

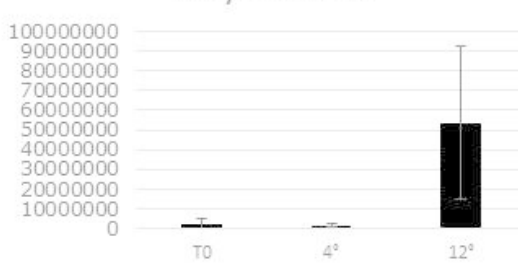

Ethyl acetate

100000000

90000000

70000000

60000000

50000000

50000000
40000000

40000000
30000000

20000000

10000000

\section{Citrus flavour}

Ethyl Alcohol

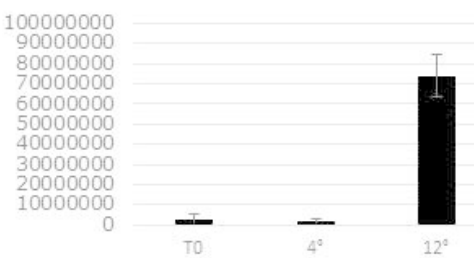

Ethyl acetate

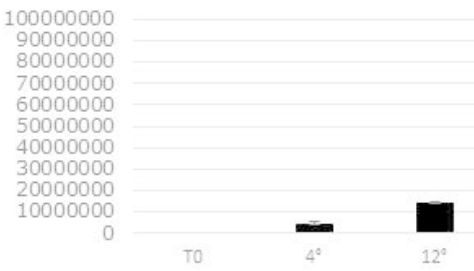

Butanoic acid, ethyl ester

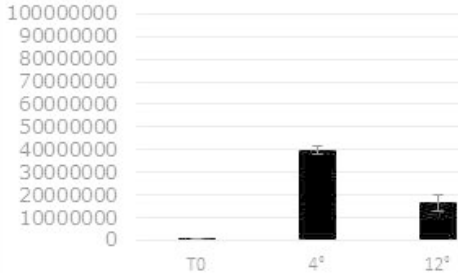

Diacetyl

100000000

90000000

80000000

60000000

50000000

40000000

30000000

20000000

10000000

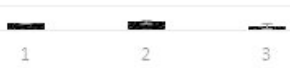

Volatile profile of sports beverage maintained at 4 and $12^{\circ} \mathrm{C}$

$190 \times 254 \mathrm{~mm}(96 \times 96$ DPI) 
Table1: Volatile organic compounds found in scotta and in the two experimental beverages at TO

\section{Raw Scotta Citrus flavour Tropical fruit flavour}

\begin{tabular}{|c|c|c|c|c|}
\hline$\Sigma$ Alcohols & & 50 & 1,27 & 2,36 \\
\hline Ethyl alchol & 1.10 & \pm 0.07 & - & - \\
\hline 1-pentanol & 1.17 & \pm 0.04 & $0.01 \pm 0.01$ & $0.42 \pm 0.01$ \\
\hline 3-Buten-2-ol & 1.00 & \pm 0.15 & - & $0.47 \pm 0.20$ \\
\hline 1-Hexanol & 0.23 & \pm 0.13 & $0.14 \pm 0.01$ & - \\
\hline 3-Hexen-1-ol & & - & - & $0.39 \pm 0.06$ \\
\hline Benzyl Alcohol & & - & - & $1.08 \pm 0.02$ \\
\hline 1-Octanol & & - & $1.11 \pm 0.03$ & - \\
\hline$\Sigma$ Aldehydes & & .77 & 1.94 & 17.60 \\
\hline Acetaldeyde & 3.30 & \pm 1.27 & $0.01 \pm 0.00$ & $0.86 \pm 0.17$ \\
\hline Hexanal & 5.29 & \pm 1.82 & - & $12.78 \pm 0.77$ \\
\hline Heptanal & 0.47 & \pm 0.10 & - & - \\
\hline Octanal & & - & $0.18 \pm 0.25$ & - \\
\hline Benzaldehyde & & - & $0.12 \pm 0.00$ & - \\
\hline Nonanal & 1.44 & \pm 0.03 & $1.55 \pm 0.06$ & - \\
\hline Decanal & 0.27 & \pm 0.00 & $0.01 \pm 0.01$ & $3.96 \pm 1.25$ \\
\hline Dodecanal & & - & $0.05 \pm 0.03$ & - \\
\hline Tridecanal & & - & $0.02 \pm 0.00$ & - \\
\hline$\Sigma$ Esters & 1. & 71 & - & 27.77 \\
\hline Ethyl acetate & & -10 & - & $2.05 \pm 0.15$ \\
\hline Butanoic acid, ethyl ester & 1.71 & \pm 0.60 & - & $0.43 \pm 0.02$ \\
\hline 3-Hexen-1-ol, acetate & & $-\quad(0$ & - & $0.41 \pm 0.03$ \\
\hline Acetic acid, hexyl ester & & - & - & $1.05 \pm 0.05$ \\
\hline 2-Hexen-1-ol, acetate & & - & - & $21.03 \pm 5.36$ \\
\hline Propanedioic acid, diethyl ester & & - & - & $1.62 \pm 0.92$ \\
\hline Isoamyl isobutyrate & & - & - & $0.69 \pm 0.21$ \\
\hline Benzil acetate & & - & - & $0.09 \pm 0.12$ \\
\hline Benzoic acid, 2-hydroxy-, methyl ester & & - & - & $0.41 \pm 0.03$ \\
\hline$\Sigma$ Acids & & 1.83 & 2.07 & 14.14 \\
\hline Acetic acid & 1.89 & \pm 0.34 & $0.02 \pm 0.01$ & $2.75 \pm 0.39$ \\
\hline Hexanoic acid & 0.99 & \pm 0.30 & $0.01 \pm 0.01$ & - \\
\hline Heptanoic acid & 0.92 & \pm 0.28 & - & - \\
\hline Sorbic Acid & & - & $1.43 \pm 0.13$ & $10.98 \pm 1.80$ \\
\hline Benzoic acid & 12.47 & \pm 3.65 & - & $0.41 \pm 0.03$ \\
\hline Octanoic acid & 3.79 & \pm 2.28 & $0.51 \pm 0.02$ & - \\
\hline Decanoic acid & 4.76 & \pm 3.24 & $0.11 \pm 0.00$ & - \\
\hline$\Sigma$ Ketones & & 5.04 & 0.08 & 12.70 \\
\hline Acetone & 4.90 & \pm 2.27 & $0.06 \pm 0.01$ & $1.36 \pm 0.15$ \\
\hline Diacetyl & 11.77 & \pm 4.61 & $0.02 \pm 0.00$ & $2.73 \pm 0.08$ \\
\hline 2 Butanone 3 methyl & 2.82 & \pm 0.49 & - & $0.68 \pm 0.06$ \\
\hline 2 Pentanone & 0.27 & \pm 0.06 & - & - \\
\hline 2,3 Pentanedione & 27.65 & \pm 3.11 & - & - \\
\hline Acetoin & 7.40 & \pm 1.49 & - & $6.60 \pm 0.85$ \\
\hline 2 Heptanone & 0.82 & \pm 0.23 & - & $1.34 \pm 0.00$ \\
\hline
\end{tabular}


2-Nonanone

2-Undecanone

$\Sigma$ Hydrocarbons

Dodecane

Tetradecane

$\Sigma$ Others

a-Phellandrene

a-Pinene

4-Carene

Camphene

$\beta$-Pinene

$\beta$-Phellandrene

2,3-Dehydro-1,8-cineole

$\beta$-Myrcene

a-Terpinene

Terpinolene

d-Limonene

Beta Ocimene

cis-Linaloloxide

Terpineol

Geraniol

Citral

Triacetin

Copaene

Caryophyllene

$$
0.41 \pm 0.04
$$

$0.01 \pm 0.00$

1.10

$0.83 \pm 0.01$

$0.27 \pm 0.03$

2.04

94.61

24.90

$0.26 \pm 0.01$

$4.06 \pm 0.78$

$0.04 \pm 0.01$

$0.41 \pm 0.13$

$1.17 \pm 0.32$

$0.06 \pm 0.08$

$0.11 \pm 0.03$

$0.04 \pm 0.01$

$2.04 \pm 0.07$

$92.76 \pm 0.01$

$0.97 \pm 0.08$

$0.91 \pm 0.05$

$9.91 \pm 0.59$

$0.05 \pm 0.00$

$0.04 \pm 0.00$

$0.07 \pm 0.00$

$7.62 \pm 0.89$

$0.01 \pm 0.00$ 